\title{
Analysis of a temporal cluster of Shigella boydii isolates in Mpumalanga, South Africa, November to December 2007
}

\author{
Anthony M. Smith ${ }^{1,2}$, Karen H. Keddy ${ }^{1,2}$, Arvinda Sooka ${ }^{1}$, Husna Ismail ${ }^{1}$, Gillian M. de \\ Jong $^{1,2}$, Greta Hoyland ${ }^{3}$, for the Group for Enteric, Respiratory and Meningeal Disease \\ Surveillance in South Africa (GERMS-SA)
}

${ }^{1}$ National Institute for Communicable Diseases, Johannesburg, South Africa
2 University of the Witwatersrand, Johannesburg, South Africa
${ }^{3}$ National Health Laboratory Service, Rob Ferreira Hospital, Nelspruit, South Africa

\begin{abstract}
Background: Shigellosis is a global human health problem. The disease is most prevalent in developing countries with poor access to safe potable water and sanitation. Shigella boydii is of particular epidemiological importance in developing nations such as African and Asian countries. In the present study, we report on the analysis of a temporal cluster of 29 S. boydii serotype 2 strains, isolated in the Mpumalanga Province of South Africa (SA) over the period of November to December 2007.

Methodology: Bacteria were identified as S. boydii using standard microbiological identification techniques and serotyped using commercially available antisera. Susceptibility testing to antimicrobial agents was determined by the Etest. Genotypic relatedness of strains was investigated by pulsed-field gel electrophoresis (PFGE) analysis of digested genomic DNA.

Results: The cluster of 29 isolates revealed comparable antimicrobial susceptibility profiles, while dendrogram analysis of PFGE patterns showed that the cluster of isolates grouped together and could clearly be differentiated from a random selection of unrelated S. boydii serotype 2 strains. Our data has strongly suggested that this cluster of isolates may share a common ancestry. However, this cannot be substantiated by epidemiological data because a detailed epidemiological investigation was not conducted.

Conclusions: We have documented the first cluster of $S$. boydii infection in SA. Due to the lack of adequate epidemiological investigation, we cannot emphatically state that an outbreak had occurred. However, we do hypothesis that this was an outbreak for which a waterborne source cannot be excluded. This study has highlighted the urgent need for timely and appropriate systems of epidemiological investigation of all suspected outbreaks of disease in developing countries.
\end{abstract}

Key words: Shigella boydii, diarrhoeal disease, cluster, water-borne

J Infect Developing Countries 2009; 3(1):65-70.

Received 16 September 2008 - Accepted 3 November 2008

Copyright $@ 2008$ Smith et al. This is an open access article distributed under the Creative Commons Attribution License, which permits unrestricted use, distribution, and reproduction in any medium, provided the original work is properly cited.

\section{Introduction}

Shigellosis is a global human health problem [1]. The disease is most prevalent in developing countries with poor access to safe potable water and sanitation. Shigella sonnei is of particular epidemiological importance in developed nations (USA and Europe), while Shigella flexneri and Shigella boydii are of particular epidemiological importance in developing nations such as African and Asian countries [2-4]. Shigella infection is commonly food-borne and can also easily be transmitted from person to person via the faecaloral route [5]. In addition, Shigella is one of five species of microorganisms most commonly associated with water-borne disease [6]. Notably, Shigella has been classified as a potential agent for biological terrorism due to its low infectious dose, route of infection, and environmental stability [7]. Recent data regarding food-borne and water-borne outbreaks of Shigella demonstrate that $S$. sonnei is the most commonly reported Shigella species associated with such outbreaks [8-11]. In contrast, outbreaks of $S$. boydii appear to be an infrequent occurrence and rarely reported. A search of published data (English language) found that the last report of an outbreak involving S. boydii occurred in Chicago, USA, in 1998 and involved bean salad infected with a serotype 18 strain, where it was alleged that parsley and cilantro ingredients introduced the contamination into the bean salad [12]. For South Africa (SA), very little data exists for outbreaks of Shigella infection, irrespective of serotype, so the frequency of such outbreaks in this country is unknown. In the present study, we report on the analysis of a temporal cluster of 29 S. boydii serotype 2 strains, isolated in the Mpumalanga Province of SA over the period of November to December 2007, henceforth referred to as the Mpumalanga cluster. 


\section{Materials and Methods}

The cluster of 29 strains were isolated from patients ranging in age from 1 year to 62 years (median age $=22$ years); all patients presented with symptoms of diarrhoea. No patient deaths were reported. Patient specimens included stools or rectal swabs. Specimens were collected from patients living in the towns of Mashishing $(n=22)$, Standerton $(n=5)$, Delmas $(n=1)$ and Ba-Mokgoko $(n=1)$. Figure 1 shows the location of towns in the province. The first specimen was collected on 7

Figure 1. Map of the Mpumalanga Province in South Africa showing the location of major towns. $\Delta$, indicates the towns associated with the cluster of S. boydii isolates.

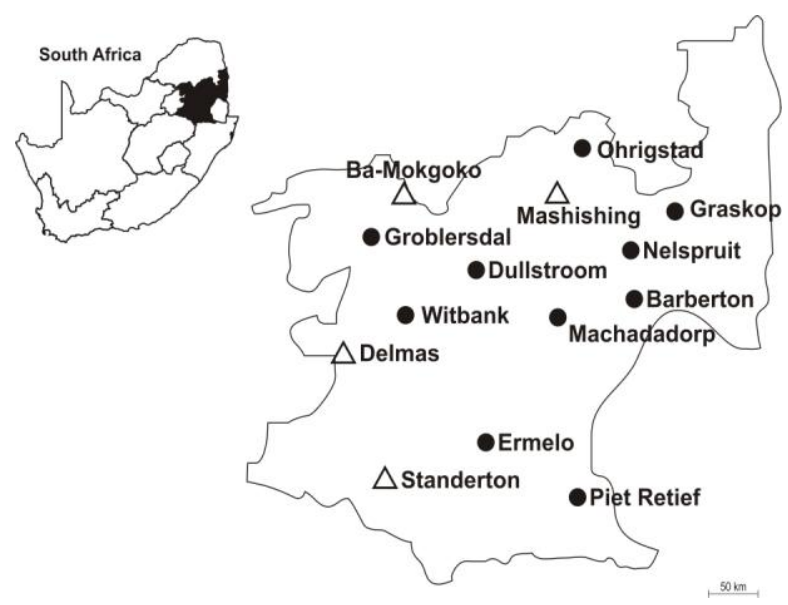

November 2007 from Delmas and the last specimen was collected on 25 December 2007 from Standerton. For comparative purposes, we included an additional $24 \mathrm{~S}$. boydii serotype 2 strains which were randomly selected from a larger group and unrelated to the Mpumalanga cluster with regards to province of isolation or date of isolation. Bacteria were identified as $S$. boydii using standard microbiological identification techniques [13] and serotyped using commercially available antisera (Mast Assure, Mast Group Ltd, Merseyside, UK) as instructed by the manufacturer. Susceptibility testing to antimicrobial agents (ampicillin, augmentin, trimethoprim, sulfamethoxazole, chloramphenicol, nalidixic acid, ciprofloxacin, tetracycline, kanamycin, streptomycin, imipenem, ceftriaxone and ceftazidime) was determined by the Etest (AB BIODISK, Solna, Sweden), as instructed by the manufacturer. The genotypic relatedness of strains was investigated by pulsed-field gel electrophoresis (PFGE) analysis of digested genomic DNA using a PulseNet protocol incorporating separate analysis with $X b a \mathrm{I}$ and NotI restriction enzymes [14]. The CHEF-DR III system (Bio-Rad Laboratories Inc., Hercules, CA, USA) was used for PFGE analysis and programmed (block 1) as follows: electrophoresis gradient, $6 \mathrm{~V} / \mathrm{cm}$; included angle, $120^{\circ}$; initial switch time, 2.2 seconds; final switch time, 63.8 seconds; run time, 22 hours.

\section{Results and Discussion}

The Enteric Diseases Reference Unit (EDRU) of the National Institute for Communicable Diseases (NICD) is a reference centre in SA for various diarrhoeal/enteric pathogens including Salmonella species, Shigella species, diarrhoeagenic Escherichia coli and Vibrio cholerae. The EDRU participates in national laboratory-based surveillance for these pathogens. Isolates are voluntarily submitted to the EDRU from $\sim 120$ clinical microbiology laboratories covering all provinces across SA. Surveillance data shows that in SA, S. flexneri is the most commonly isolated Shigella species in humans. For the years 2005 and 2006, S. flexneri accounted for 79\% (1756/2217) of all Shigella isolates (K. H. Keddy, unpublished data). In contrast, S. boydii is an infrequent isolate. For the years 2005 and 2006, only 38 strains of $S$. boydii were isolated in SA, of which 23 strains were $S$. boydii serotype 2. For this period, in the Mpumalanga Province of SA, only a single $S$. boydii strain was isolated, a $S$. boydii serotype 2 strain isolated in February 2005. It is within this context that the sudden emergence of a cluster of 29 isolates of $S$. boydii serotype 2 in Mpumalanga over the period November to December 2007 suggested that an outbreak was occurring. The increased numbers of infections due to this serotype in the year $2007(53 / 1230,4 \%)$ versus the years 2003 to $2006(45 / 3832,1 \%)$ meant that $S$. boydii infection was 3.8 times more likely in the year 2007 than in the years 2003 to $2006(\mathrm{P}=0.0001 \quad[95 \%$ $\mathrm{CI}=2.48-5.80]$ ). Table 1 shows the number of $S$. boydii serotype 2 infections in the nine provinces of SA for the years 2005 to 2007 . There were very few isolates annually followed by the sudden emergence of 29 isolates in Mpumalanga over the period November to December 2007. 
Table 1. Number of S. boydii serotype 2 infections in the 9 provinces of South Africa for the years 2005 to 2007 (the value in parenthesis shows the number of $S$. boydii serotype 2 infections as a percentage of the total number of Shigella infections for that year).

\begin{tabular}{|c|c|c|c|c|c|c|c|c|c|c|}
\hline & & \multicolumn{9}{|c|}{ Province } \\
\hline & & $\begin{array}{l}\text { Eastern } \\
\text { Cape }\end{array}$ & $\begin{array}{l}\text { Western } \\
\text { Cape }\end{array}$ & $\begin{array}{l}\text { Northern } \\
\text { Cape }\end{array}$ & Gauteng & Free State & $\begin{array}{l}\text { KwaZulu- } \\
\text { Natal }\end{array}$ & Limpopo & $\begin{array}{l}\text { North } \\
\text { West }\end{array}$ & Mpumalanga \\
\hline \multirow[t]{3}{*}{ Year } & 2005 & $0(0 \%)$ & $5(0.47 \%)$ & $0(0 \%)$ & $3(0.28 \%)$ & $1(0.09 \%)$ & $2(0.19 \%)$ & $0(0 \%)$ & $1(0.09 \%)$ & $1(0.09 \%)$ \\
\hline & 2006 & $1(0.09 \%)$ & $3(0.26 \%)$ & $0(0 \%)$ & $3(0.26 \%)$ & $0(0 \%)$ & $1(0.09 \%)$ & $0(0 \%)$ & $2(0.18 \%)$ & $0(0 \%)$ \\
\hline & 2007 & $0(0 \%)$ & $4(0.33 \%)$ & $0(0 \%)$ & $12(0.98 \%)$ & $2(0.16 \%)$ & $4(0.33 \%)$ & $1(0.08 \%)$ & $1(0.08 \%)$ & $29(2.36 \%)$ \\
\hline
\end{tabular}

These 29 isolates were identified during the investigation of several outbreaks of watery diarrhoea occurring in several districts of the province, which overwhelmed available resources for epidemiological investigation in this country. The unusual predominance of this serotype, in one area in particular, initiated a genotypic analysis of this cluster of strains to determine their clonal relatedness.

The cluster of $29 \mathrm{~S}$. boydii isolates revealed comparable antimicrobial susceptibility profiles. All isolates (except the Delmas isolate) showed resistance to ampicillin [minimum inhibitory concentration (MIC), $256 \mu \mathrm{g} / \mathrm{ml}$, trimethoprim (MIC, $32 \mu \mathrm{g} / \mathrm{ml}$ ), sulfamethoxazole (MIC, 1024 $\mu \mathrm{g} / \mathrm{ml}$ ) and streptomycin (MICs, 192-512 $\mu \mathrm{g} / \mathrm{ml}$ ). Susceptibility was shown to augmentin (MICs, 4$8 \mu \mathrm{g} / \mathrm{ml}$ ), chloramphenicol (MICs, $1.5-2 \mu \mathrm{g} / \mathrm{ml}$ ), nalidixic acid (MICs, $1.5-2 \mu \mathrm{g} / \mathrm{ml}$ ), ciprofloxacin (MICs, 0.008-0.064 $\mu \mathrm{g} / \mathrm{ml}$ ), tetracycline (MICs, 1.5-4 $\mu \mathrm{g} / \mathrm{ml}$ ), kanamycin (MICs, 3-6 $\mu \mathrm{g} / \mathrm{ml}$ ), imipenem (MICs, 0.19-0.38 $\mu \mathrm{g} / \mathrm{ml}$ ), ceftriaxone (MICs, $0.032-0.064 \mu \mathrm{g} / \mathrm{ml}$ ) and ceftazidime (MICs, 0.047-0.125 $\mu \mathrm{g} / \mathrm{ml}$ ). The Delmas isolate showed slight differences in its susceptibility profile in that it was susceptible to sulfamethoxazole (MIC, $4 \mu \mathrm{g} / \mathrm{ml}$ ) and streptomycin (MICs, $8 \mu \mathrm{g} / \mathrm{ml}$ ). Within the enteric group of bacteria, resistance genes coding for sulfamethoxazole and streptomycin are commonly located on mobile genetic elements (integrons, transposons and plasmids) of a promiscuous nature. The loss of such a mobile element in the Delmas isolate could explain the loss of resistance to sulfamethoxazole and streptomycin. Dendrogram analysis of PFGE patterns (XbaI digestion) showed that the Mpumalanga cluster of
29 strains grouped together on the dendrogram and could clearly be differentiated from a random selection of unrelated serotype 2 strains (Figure 2). The Mpumalanga cluster was represented by five unique (but similar) PFGE patterns. Four of these patterns were each represented by an individual isolate, while the fifth pattern was represented by 25 isolates [for these 25 isolates, PFGE analysis with a second restriction enzyme (NotI) also revealed an indistinguishable pattern (data not shown)]. Following this Mpumalanga cluster, another two strains of serotype 2 were isolated from the same area from specimens taken on 29 January 2008 and on 14 February 2008; however, PFGE patterns (XbaI digestion) showed them to be unrelated to the Mpumalanga cluster strain. To verify that PFGE analysis ( $\mathrm{X} b a \mathrm{I}$ digestion) is a valid genotypic method to differentiate SA strains of $S$. boydii serotype 2, we also performed PFGE analysis on 24 sporadic isolates of $S$. boydii serotype 2; these were randomly selected from a larger group and unrelated to the Mpumalanga cluster with regards to province of isolation or date of isolation. Dendrogram analysis of PFGE patterns showed that these 24 sporadic isolates could clearly be differentiated from our Mpumalanga cluster (Figure 2). These 24 sporadic isolates were differentiated into 22 unique PFGE patterns proving that this method is able to differentiate SA strains of $S$. boydii serotype 2 . PFGE analysis incorporating $X b a \mathrm{I}$ digestion has previously been shown to be an appropriate method for subtyping strains of $S$. boydii $[15,16]$ and our current study corroborates this.

Our laboratory investigation has strongly suggested that the current Mpumalanga cluster of $S$. boydii strains may share a common ancestry. However, this cannot be substantiated by epidemiological data because a detailed epidemiological investigation 
Figure 2. Dendrogram of PFGE fingerprint patterns (XbaI digestion) for S. boydii isolates showing the Mpumalanga cluster of isolates as compared to sporadic unrelated isolates.

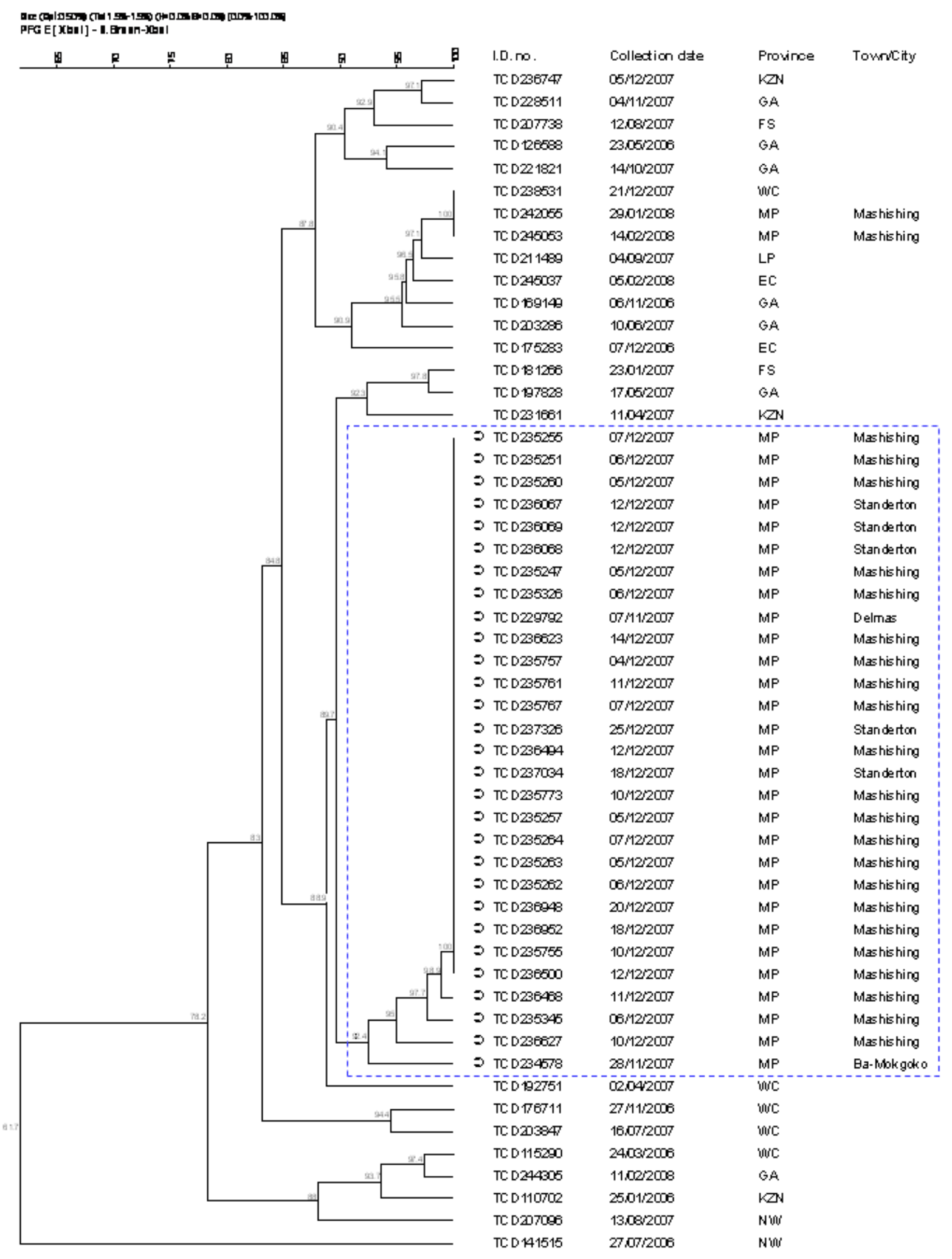


was not conducted, although statistical data support this premise. The minimal patient data collected were insufficient to provide further support for our laboratory findings. No data exist for travel history or other exposures for that time period and we were therefore unable to formulate a hypothesis regarding a likely source of infection. However, other diarrhoeal disease outbreaks occurring in surrounding areas were believed to be water-borne. We have no data on quality of household water amongst these cases but they are resident in rural areas of a province where safe potable water may not be available. This province has been plagued by regular outbreaks of water-borne disease, such as the outbreaks of typhoid fever in Delmas in 1993 [17] and 2005 (K. H. Keddy, unpublished data). Also, from 14 October 2007 to 9 December 2007, there were 1,301 cases of diarrhoea reported from Delmas. Stool and rectal swabs from these patients detected a diverse group of pathogens including Shigella, Salmonella, diarrhoeagenic E. coli, adenovirus, astrovirus, norovirus, rotavirus, Schistosoma mansoni, Gardia lamblia and Isospora belli (G. M. de Jong, personal

\section{Acknowledgements}

We thank the communicable disease control coordinators of the Departments of Health and Social Services, Mpumalanga, for their assistance in investigation of outbreaks of disease. We thank Penny Crowther for assistance with statistical analysis of data.

\section{Members of GERMS-SA}

Sandeep Vasaikar (University of Transkei, Mthatha, Eastern Cape); Nolan Janse van Rensberg, André Möller, AnneMarie Pretorius, Peter Smith (University of the Free State, Bloemfontein, Free State); Khatija Ahmed, Anwar Hoosen, Ruth Lekalakala, Donald Ngwira, Pyu Pyu Sein (University of Limpopo - Medunsa Campus, Garankuwa, Gauteng); Heather Crewe-Brown, Charles Feldman, Alan Karstaedt, Olga Perovic, Jeannette Wadula (University of the Witwatersrand, Johannesburg, Gauteng); Mike Dove, Kathy Lindeque, Linda Meyer, Gerhard Weldhagen (University of Pretoria, Pretoria, Gauteng); Prathna Bhola, Prashini Moodley, Sharona Seetharam, Sindiswe Sithole, Wim Sturm, Trusha Vanmali (University of KwaZulu Natal, Durban, KwaZulu Natal); Ken Hamese (Polokwane/Mankweng Hospital Complex, Polokwane, Limpopo); Keith Bauer, Greta Hoyland, Jacob Lebudi, Charles Mutanda (National Health Laboratory Service, Mpumalanga); Rena Hoffmann, Lynne Liebowitz, Elizabeth Wasserman (University of Stellenbosch, Stellenbosch, Western Cape), Denise Roditi, John Simpson, Andrew Whitelaw (University of Cape Town, Cape Town, Western Cape); Adrian Brink (AMPATH laboratories, Johannesburg, Gauteng); Claire Heney (Lancet communication). This extremely diverse array of pathogens provides strong evidence for a water-borne source.

In conclusion, we have documented the first cluster of $S$. boydii infection in SA. No detailed epidemiological investigation was conducted, so we cannot emphatically state that an outbreak had occurred. However, we do hypothesize that this was an outbreak for which a water-borne source cannot be excluded. This study has highlighted the implications of the lack of adequate epidemiological investigation of a suspected outbreak. Without a proper epidemiological investigation, we can never say for certain that an outbreak has or has not occurred, nor can we accurately speculate on the source of the outbreak. The major reason for the lack of epidemiological investigations is the lack of resources. This is a major problem in SA and most other developing countries, including most African countries. SA is still in its infancy when it comes to investigation of outbreaks. Timely and appropriate systems for epidemiological investigation of all suspected outbreaks of disease in SA need to be prioritized and urgently put in place.

laboratories, Johannesburg, Gauteng); Marthinus Senekal (PathCare laboratories, Cape Town, Western Cape); Cheryl Cohen, Mireille Cheyip, Linda de Gouveia, John Frean, Nelesh Govender, Karen Keddy, Kerrigan McCarthy, Susan Meiring, Elizabeth Prentice, Vanessa Quan, Koshika Soma, Anne von Gottberg (National Institute for Communicable Diseases, Johannesburg, Gauteng).

\section{References}

1. Niyogi SK (2005) Shigellosis. J Microbiol 43: 133-143.

2. Kotloff KL, Winickoff JP, Ivanoff B, Clemens JD, Swerdlow DL, Sansonetti PJ, Adak GK, Levine MM (1999) Global burden of Shigella infections: implications for vaccine development and implementation of control strategies. Bull World Health Organ 77: 651-666.

3. Gupta A, Polyak CS, Bishop RD, Sobel J, Mintz ED (2004) Laboratory-confirmed shigellosis in the United States, 1989-2002: epidemiologic trends and patterns. Clin Infect Dis 38: 1372-1377.

4. Pazhani GP, Niyogi SK, Singh AK, Sen B, Taneja N, Kundu M, Yamasaki S, Ramamurthy T (2008) Molecular characterization of multidrug-resistant Shigella species isolated from epidemic and endemic cases of shigellosis in India. J Med Microbiol 57: 856-863.

5. Shiferaw B, Shallow S, Marcus R, Segler S, Soderlund D, Hardnett FP, Van GT (2004) Trends in population-based active surveillance for shigellosis and demographic variability in FoodNet sites, 1996-1999. Clin Infect Dis 38 Suppl 3: 175-180. 
6. Ford TE (1999) Microbiological safety of drinking water: United States and global perspectives. Environ Health Perspect 107 Suppl 1: 191-206.

7. Rotz LD, Khan AS, Lillibridge SR, Ostroff SM, Hughes JM (2002) Public health assessment of potential biological terrorism agents. Emerg Infect Dis 8: 225-30.

8. Lewis HC, Kirk M, Ethelberg S, Stafford R, Olsen K, Nielsen EM, Lisby M, Madsen SB, Molbak K (2007) Outbreaks of shigellosis in Denmark and Australia associated with imported baby corn, August 2007 - final summary. Euro Surveill 12. Available: http://www.eurosurveillance.org/ViewArticle.aspx?Articl eId=3279. Accessed 3 October 2008 .

9. Kimura AC, Johnson K, Palumbo MS, Hopkins J, Boase JC, Reporter R, Goldoft M, Stefonek KR, Farrar JA, Van Gilder TJ, Vugia DJ (2004) Multistate shigellosis outbreak and commercially prepared food, United States. Emerg Infect Dis 10: 1147-1149.

10. Terajima J, Tosaka N, Ueno K, Nakashima K, Kitsutani P, Gaynor MK, Park SY, Watanabe H (2006) Shigella sonnei outbreak among Japanese travelers returning from Hawaii. Jpn J Infect Dis 59: 282-283.

11.Coba-Florez J, Perz-Roth E, Gonzalez-Linares S, MendezAlvarez S (2005) Outbreak of Shigella sonnei in a rural hotel in La Gomera, Canary Islands, Spain. Int Microbiol 8: 133-136.

12. Chan YC, Blaschek HP (2005) Comparative analysis of Shigella boydii 18 foodborne outbreak isolate and related enteric bacteria: role of rpoS and adiA in acid stress response. J Food Prot 68: 521-527.

13. Winn WC, Allen SD, Janda WM, Koneman EW, Procop GW, Schreckenberger PC, Woods GL (2006) The
Enterobacteriaceae. Koneman's color atlas and textbook of diagnostic microbiology, $6^{\text {th }}$ edition. Philadelphia: Lippincott Williams \&Wilkens, 211-302.

14. Ribot EM, Fair MA, Gautom R, Cameron, DN, Hunter SB, Swaminathan B, Barrett TJ (2006) Standardization of pulsed-field gel electrophoresis protocols for the subtyping of Escherichia coli O157:H7, Salmonella, and Shigella for PulseNet. Foodborne Pathog Dis 3: 59-67.

15. Woodward DL, Clark CG, Caldeira RA, Ahmed R, Soule G, Bryden L, Tabor H, Melito P, Foster R, Walsh J, Ng LK, Malcolm GB, Strockbine N, Rodgers FG (2005) Identification and characterization of Shigella boydii 20 serovar nov., a new and emerging Shigella serotype. J Med Microbiol 54: 741-748.

16. Ansaruzzaman M, Sultana M, Talukder KA, Alam K, Matsushita S, Safa A, Khajanchi BK, Dutta DK, Islam Z, Albert MJ, Nair GB, Sack DA (2005) Isolation and characterization of provisional serovar Shigella boydii E16553 from diarrhoeal patients in Bangladesh. J Med Microbiol 54: 477-480.

17. Waner S, Kfir R, Idema GK, Coetzee DJ, Rasmussen K, Koornhof HJ, Klugman KP (1998) Waterborne outbreak of typhoid fever in Delmas. Southern Afr J Epidemiol Infect 13: 53-57.

Corresponding author: Dr. Anthony Smith Enteric Diseases Reference Unit, National Institute for Communicable Diseases, Private Bag X4, Sandringham, 2131, South Africa

Tel: +27-11-5550348, Fax: +27-11-5550433

Email: anthonys@nicd.ac.za 